\title{
GENETIC GAIN AND SELECTION CRITERIA EFFECTS ON LINT YIELD AND YIELD COMPONENTS IN SEGREGATING POPULATION (GIZA $88 \times$ A 13 )
}

\author{
B. M. Ramdan \\ Cotton Research Institute, Agriclture Research Center, Giza Egypt.
}

Received: Feb. 28 , 2021

Accepted: Mar. 28, 2021

ABSTRACT: Gains from application Index selection are very important in cotton breeding program, thus the main objective of this study was to estimate the genetic advance obtained by application of fifteen selection procedures, 11 indices and 4 pedigree line selection after two cycles to improve lint yield and other components with acceptable fiber quality in early segregating population of cross (G.88* $A$ 13). The data showed increased in mean performances for all characters with advanced generations from $F_{2}$ to $F_{4}$ indicating an accumulation of favorable alleles. The advanced generations $F_{3}$ and $F_{4}$ showed reduction in PCV and GCV as compared with $F_{2}$ generation. Most characters showed high heritability values in broad sense over $60 \%$. Genotypic correlations in most cases were higher than phenotypic ones in both $F_{2}$ and $F_{3}$ generations. Lint yield I plant, seed cotton yield I plant, bolls I plant showed highly significant positive desirable phenotypic and genotypic correlation with other yield contributed characters in both $F_{2}$ and $F_{3}$ generations. Boll weight showed desirable significant correlations with other yield characters in both $F_{2}$ and $F_{3}$ generations. The genetic correlation between fiber length and fiber strength was highly significant positive. The undesirable negative correlation which existed between fiber length with other yield characters in $F_{2}$ and $F_{3}$ generations were broken and converted to desirable values. The highest predicted genetic advance from $F_{2}$ and $F_{3}$ generations were obtained with the index I.w12 followed by I.w2 and I.w23 This was true since lint yield /plant showed significant positive correlation with the other yield contributed characters. The highest actual genetic gains from $F_{3}$ generation for lint yield /plant occurred by $I_{w_{123}}$, I $I_{12}$ and most selection indices. Maximum predicted genetic advance for lint yield $/$ plant from $F_{3}$ and $F_{4}$ generations were achieved when selecting for three components lint yield/plant, bolls/plant and seeds/ boll as well as for lint yield/plant alone. Selection for lint yield Iplant alone gave moderate predicted and actual value in three generations followed by index involved lint yield /plant with bolls/plant. The direct selection for seeds/ boll and selection for lint /seed gave low predicted advance in lint yield. Deviation of the actual advance from the predicted ones were positive and low for most indices, which due to the minor relatively role of non -additive effects and the additive genetic effective would appear to be predominant. On the other side high discrepancy was observed between predicted and actual gains from selection when applied selection for seeds/boll, lint Iseed and selection index for seeds/boll with lint/seed this was due to non-additive gene effect and large affected by environmental factors High discrepancy was observed between predicted and actual gains from selection for most procedures and advance would decrease in $F_{4}$ generation as compared with $F_{3}$ for all characters. The role of selection in improvement is that acts on the genetic variances within a population, isolates and increases the desired genetic frequency within the population, and thus, the population means changes towards to a desired value. Thus breeder could selected some families which characterized by high yielding capacity with acceptable fiber 
properties and utilize such selected families in breeding program aiming to improvement yield and quality in cotton.

Key words: Predicted gain, Realized gain, Selection procedures, cotton, improvement, selection index.

\section{INTRODUCTION}

Cotton breeders relay to increase the frequency of combinations which possessed the desirable characters to evolve high yielding varieties with acceptable fiber quality. Improving lint yield, yield components and fiber quality are important objectives in breeding cotton. Gain from selection in a breeding program depend on genetic variation within a population for a given trait, heritability of that trait, and selection intensity (Falconer 1981) .

Since yield is known to be a complex trait and highly affected by environmental conditions, thus, direct selection for yield is not expected to be effective. Therefore, breeder avoids selection for yield and prefers to select for its components individually. The choice of selection and breeding procedures for genetic improvement of cotton is largely conditioned by the type and relative amount of genetic variances component in the population while, the gain from selection in a population depends on genetic variability, heritability and selection intensity ( Falconer, 1989 ). The exploitation of genetically diverse stock in cross combinations helps to identify promising hybrids and $I$ or develop superior lines.

The cotton breeding includes several agronomic and fiber traits, whose association may interfere in the selection process (Araujo et al., 2012). The knowledge of those correlations allows measuring the magnitude of the relationship between several traits of the plant and determines the traits on which the selection can be based, to improve yield and the other fiber quality ( Iqbal et al., 2006 and Desalegn et al., 2009 ).

Selection of superior progenies is a procedure intensive process, once the traits of importance are strongly influenced by the environment and often correlated, so that a selection in one provokes in the others. Therefore, selection to develop superior genotypes based on one or a few traits might be little effective, since a genotype may be obtained that performance superior in relation to the selected trait only (Ramadan et al. ( 2014 ) and El -Mansy 2015 ).

Using of selection index, which is multiple regression of genotypic values on phenotypic values of several traits, and are generally used to discriminate among selection units by taking into account both of the genetic and statistical structure of the population from which the genotypic originated, as well as the economic importance of the traits. (Jesus et al., 2006). The use of selection index is superior in improving complex traits. Furthermore selection index aimed at determining the most valuable genotypes as well as the most suitable combinations of traits with the extension of indirectly the yield in different plants. (El-Lawendey et al., 2011, El-lawendey and El-Dahan, 2012 and EI Mansy, 2015).

Thus, the goal of the present study was to estimate and evaluate the efficiency of selection indices and compare it with direct and indirect selection for some economic characters. 


\section{MATERIALS AND METHODS}

\section{Genetic materials and selection procedures:}

The present study was carried out at Sakha Agricultural Research Station, during 2017, 2018 and 2019 growing seasons. The materials used were the $F_{2}$, $F_{3}$ and $F_{4}$ generations of an intra specific cotton (Gossypium barbadense L.) cross (G.88 X A 13). Self pollination was practiced for all $F_{2}$ plants. Selfed as well as open pollinated bolls/plant of 200 guarded plants and picked up separately and the total seed cotton yield/plant was ginned and lint yield /plant, bolls/plant, seeds/boll, lint/seed, boll weight, seed index and lint percentage were determined.

Using $5 \%$ selection intensity the plants having the highest performance in each selection procedures were saved. These gave a total of $32 F_{3}$ selected progenies. Ten superior progenies from each selection procedure).In 2018 season, part of selfed seeds of 32 selected progenies were evaluated with a random sample of bulked seed of $F_{3}$ generation in a randomized complete blocks design with three replicates. Experimental plot was of single row as carried in 2018.The 32 progenies were ranked using fifteen selection procedures. The two superior progenies of each selection procedures were selected using $5 \%$ selection intensity. In 2019 season, selfed seeds of selected progenies (18 progenies) were evaluated with a random sample of bulked seed of $F_{4}$ generation and two original parents in a randomized complete blocks design with three replicates. Experimental plot was lay out as same as carried out in 2015. The planting dates were last April 2017, 2018 and 2019seasons. All recommended agronomic practice was applied during the growing season.
Selection procedures were as follows:

Selection indices :

\begin{tabular}{|l|l|l|l|l|l|l|l|l|l|l|}
\hline I.w123 & I. 12 & I. 113 & I.w23 & I.123 & I.w1 & I.w2 & I.w3 & I. 12 & I. 13 & I.23 \\
\hline
\end{tabular}

Direct selection :

$\begin{array}{llll}\text { I.xw } & \text { I.x1 } & \text { I.x2 } & \text { I.x3 }\end{array}$

I. refer to index, $W$ refer to lint yield $I$ plant, X1 refer to bolls I plant, X2 refer to seeds/ boll and X3 refer to lint I seed trait.

For example; I.w123 indicates Selection index involving lint yield/plant, bolls/plant, seeds/boll and lint/seed.

The studied characters were;-

1- Boll weight $\mathrm{g}$

2- Seed cotton yield / plant $g$ (SCY)

3- Lint cotton yield / plant $\mathrm{g}(\mathrm{Xw})$ (LCY)

4- Lint percentage $\quad$ (L.P.\%)

5- Seed index $\mathbf{g}$

6- Lint $/$ seed $g$ ( X3)

7- Seeds/boll (X2)

8- Bolls/plant (X1)

9- Micronaire reading

10- Fiber strength Presly index (F.S.)

11- Fiber length at $2.5 \%$ span length $\mathrm{mm}$ (F.L.)

12- Uniformity ratio

(UR \% )

Statistical and genetic analysis ;

Heritability in broad sense was calculated according to the following expressions.

$\mathrm{h}_{\mathrm{b}}^{2}\left(\right.$ in $\mathrm{F}_{2}$ generation $)=\frac{\mathrm{VF}_{2}-\left(\mathrm{VP} 1+\mathrm{VP}_{2}\right) / 2}{\mathrm{VF}_{2}} \times 100$

$\mathrm{h}_{\mathrm{b}}^{2}\left(\right.$ in $\mathrm{F}_{3}$ and $\mathrm{F}_{4}$ generation $)=\frac{\sigma^{2} \mathrm{~g}}{\sigma^{2} \mathrm{p}} \times 100$ ( Walker 1960)

Where:

$V_{F 2}=$ The phenotypic variance of the $F_{2}$ population.

$V_{P 1}=$ The variance of the first parent

$\mathrm{V}_{\mathrm{P} 2}=$ The variance of the second parent.

$\sigma_{g}^{2}=$ The genotypic variance of the $F_{3}$ and $F_{4}$ generations.

$\sigma_{p}^{2}=$ The phenotypic variance of the $F_{3}$ and $F_{4}$ generations. 
The phenotypic and genotypic coefficients of variation were estimated using the formula developed by Kearsy and Pooni (1996).

Phenotypic and genotypic correlations coefficients between the studied characters in the three generations were also, computed according to Falconor and Mackey (1996).

The relative importance or economic values $\left(a_{i}\right)$ was caleulated according to Walker (1960).

$a_{w}$ (lint yield/plant $)=\overline{X_{1}} \cdot \bar{X}_{2} \cdot X_{3}$

$a_{1}$ (bolls/plant) $=\underline{X}_{2} \cdot X_{3}$

$a_{2}$ (seeds $\left./ b o l l\right)=X_{1} \cdot X_{3}$

$a_{3}($ lint $/$ seed $)=X_{1} \cdot X_{2}$

Where: $X$ 's represent the mean values of the studied characters.

The appropriate index weights (b's) were calculated from the following formula postulated by Smith(1936) and Hazel(1943):

(b) $=(P)^{-1} \cdot(G) \cdot(a)$

Where:

(b) = Vector of relative index coefficients,

$(P)^{-1}=$ Inverse phenotypic variancecovariance matrix,

(G) = Genotypic variance-covariance matrix and

(a) =Vector of relative economic values.

The formula suggested by Smith (1936) and Hazel (1943) was used in calculating various selection indices:

$I=b_{1} x_{1}+b_{2} x_{2}+\ldots \ldots \ldots \ldots+b_{n} x_{n}$

Predicted improvement in lint yield on the basis of an index was estimated according to the following expression:

Selection advance $(S A)=S D\left(\sum b_{i} . \sigma g_{i w}\right)^{1 / 2}$ (Walker 1960)

Where:

SD denotes selection differential in standard units.

$b_{i}$ denotes index weights for characters considered in an index. $\sigma \mathrm{g}_{\text {iw }}$ denotes genotypic covariance's of the characters with yield.

Predicted genetic advance in lint yield based on pedigree selection was estimated from the following expression: $\left(\Delta G_{w}\right)$ due to selection for $\mathrm{X}_{\mathrm{i}}=\mathrm{K} . \sigma \mathrm{g}_{\mathrm{wi}} / \sigma \mathrm{p}_{\mathrm{i}}$ (Miller and Rawlings 1967).

Also, the predicted response in any selected and unselected character was calculated as suggested by Robinson et al., (1951) and Walker (1960).

The realized gains was calculated as deviation of generation mean for each character from procedure mean of that character.

\section{RESULTS AND DISCUSSION}

The analysis of variance revealed significant differences among the materials for all studied characters in all generations i.e. $F_{2}, F_{3}$ and $F_{4}$ generations. Segregating populations with high mean performance are relatively effective in identifying the superior recombinants. A comparison of mean performance of different studied characters among the three generations, $F_{2}, F_{3}$ and $F_{4}$ revealed increase in mean performance for all characters with advanced generations from $F_{2}$ to $F_{4}$, indicating an accumulation of favorable alleles. This shifting in mean values in desirable direction could largely be attributed to the predominant of additive and additive by additive type of gene action, and also be due to the efficiency of selection procedures application in this study, which agreed with El-Lawendey et al., (2008), Ramdan et al., (2014). The range on index of variability was comparatively wider in $F_{2}$ generation as compared with the $F_{4}$ generation for most studied characters (Table 1). The lower limits of range were low in basic population $\left(F_{2}\right)$ generation compared with advanced generations $F_{3}$ and $F_{4}$ for all studied characters leading to wider spectrum of variability . 
Table (1): Means, range, phenotypic (PCV) and genotypic (GCV) coefficients of variation, phenotypic (VP) and genotypic (VG) variances and heritability values in broadsense for all characters in three generations.

\begin{tabular}{|c|c|c|c|c|c|c|c|c|c|c|}
\hline Gener. & Char. & MEAN & Range & Sx & VE & VG & VP & $\mathrm{H}$ & GCV & PCV \\
\hline$F 2$ & \multirow{3}{*}{$W$} & 2.7295 & $2.2-3.5$ & 0.017 & 0.032 & 0.027 & $0.059^{* *}$ & 46.24 & 6.07 & 8.92 \\
\hline F3 & & 3.17 & $2.6-3.8$ & 0.250 & 0.014 & 0.036 & $0.050^{* *}$ & 71.27 & 5.96 & 7.07 \\
\hline$F 4$ & & 3.192 & $3.0-3.5$ & 0.121 & 0.003 & 0.012 & $0.015^{\star \star}$ & 81.12 & 3.41 & 3.78 \\
\hline$F 2$ & \multirow{3}{*}{ SCYIP } & 59.84 & $15.9-155.2$ & 1.613 & 70.945 & 449.118 & $520.063^{\star \star}$ & 86.36 & 35.42 & 38.11 \\
\hline F3 & & 89.81 & $45.5-138.3$ & 20.420 & 23.300 & 384.450 & $407.750^{\star * *}$ & 94.29 & 21.83 & 22.48 \\
\hline$F 4$ & & 102.553 & $75.3-131.5$ & 14.096 & 2.018 & 196.668 & $198.686^{\star \star *}$ & 98.98 & 13.67 & 13.74 \\
\hline$F 2$ & \multirow{3}{*}{ LCYIP } & 22.249 & $6.5-59.9$ & 0.609 & 9.952 & 64.224 & $74.176^{* *}$ & 86.58 & 36.02 & 38.71 \\
\hline F3 & & 34.52 & $18.1-53.1$ & 7.700 & 4.290 & 52.843 & $57.133^{* *}$ & 92.49 & 21.06 & 21.90 \\
\hline F4 & & 39.283 & $29.4-52.5$ & 5.636 & 0.410 & 31.353 & $31.763^{* *}$ & 98.71 & 14.25 & 14.35 \\
\hline$F 2$ & \multirow{3}{*}{ L.P.\% } & 37.128 & $31.7-41.2$ & 0.128 & 1.568 & 1.699 & $3.266^{* *}$ & 52.00 & 3.51 & 4.87 \\
\hline F3 & & 38.52 & $34.9-41.7$ & 1.780 & 0.131 & 2.997 & $3.128^{* *}$ & 95.81 & 4.49 & 4.59 \\
\hline$F 4$ & & 38.293 & $35.4-40.5$ & 1.404 & 0.041 & 1.930 & $1.972^{\star *}$ & 97.91 & 3.63 & 3.67 \\
\hline$F 2$ & \multirow{3}{*}{ B/P } & 21.985 & $5.7-50.3$ & 0.588 & 9.937 & 59.164 & $69.101^{\star *}$ & 85.62 & 34.99 & 37.81 \\
\hline F3 & & 28.53 & $16.0-45.6$ & 6.930 & 3.070 & 43.700 & $46.770^{\star *}$ & 93.44 & 23.17 & 23.97 \\
\hline$F 4$ & & 32.239 & $22.1-42.8$ & 4.911 & 0.383 & 23.739 & $24.122^{\star \star}$ & 98.41 & 15.11 & 15.23 \\
\hline$F 2$ & \multirow{3}{*}{ SI } & 9.8825 & $8.4-12.3$ & 0.041 & 0.113 & 0.218 & $0.331^{* *}$ & 65.90 & 4.72 & 5.82 \\
\hline F3 & & 11.22 & $9.6-12.8$ & 0.650 & 0.059 & 0.136 & $0.195^{* *}$ & 69.58 & 3.28 & 3.93 \\
\hline$F 4$ & & 11.267 & $10.4-12.4$ & 0.388 & 0.018 & 0.133 & $0.151^{\star *}$ & 88.32 & 3.24 & 3.44 \\
\hline$F 2$ & \multirow{3}{*}{ S/B } & 17.032 & $13.7-21.8$ & 0.110 & 1.353 & 1.053 & $2.406^{* *}$ & 43.77 & 6.03 & 9.11 \\
\hline F3 & & 19.35 & $14.7-23.8$ & 2.080 & 0.666 & 3.193 & $3.859^{* *}$ & 82.74 & 9.23 & 10.15 \\
\hline$F 4$ & & 20.333 & $18.0-22.8$ & 1.437 & 0.063 & 2.002 & $2.065^{* \star}$ & 96.97 & 6.96 & 7.07 \\
\hline$F 2$ & \multirow{3}{*}{ L/S } & 0.05846 & $0.0417-0.0707$ & 0.000400 & 0.000015 & 0.000015 & $0.000030^{* *}$ & 50.00 & 6.63 & 9.37 \\
\hline F3 & & 0.07000 & $0.0500-0.0800$ & 0.010000 & 0.000016 & 0.000015 & $0.000031^{\star \star}$ & 48.54 & 5.49 & 7.88 \\
\hline$F 4$ & & 0.07000 & $0.0595-0.0837$ & 0.005400 & 0.000001 & 0.000028 & $0.000029^{* *}$ & 96.00 & 7.58 & 7.73 \\
\hline$F 2$ & \multirow{3}{*}{ Mic } & 3.9985 & $3-5$ & 0.023 & 0.045 & 0.065 & $0.110^{* *}$ & 59.32 & 6.37 & 8.28 \\
\hline F3 & & 4.13 & $2.9-5.2$ & 0.410 & 0.014 & 0.143 & $0.157^{* *}$ & 91.08 & 9.16 & 9.60 \\
\hline$F 4$ & & 4.063 & $3.2-4.7$ & 0.337 & 0.006 & 0.107 & $0.113^{* *}$ & 94.67 & 8.07 & 8.29 \\
\hline$F 2$ & \multirow{3}{*}{ FS } & 9.5165 & $8.7-10.5$ & 0.030 & 0.082 & 0.093 & $0.175^{*}$ & 52.94 & 3.20 & 4.40 \\
\hline F3 & & 10.88 & $9.4-12.5$ & 0.610 & 0.073 & 0.090 & $0.162^{*}$ & 55.35 & 2.76 & 3.70 \\
\hline$F 4$ & & 11.294 & $10.2-12.2$ & 0.435 & 0.022 & 0.167 & $0.189^{* *}$ & 88.20 & 3.62 & 3.85 \\
\hline$F 2$ & \multirow{3}{*}{ UR \% } & 84.151 & $81-86.9$ & 0.090 & 1.072 & 0.546 & $1.617^{* *}$ & 33.73 & 0.88 & 1.51 \\
\hline F3 & & 85.39 & $82-89.5$ & 1.670 & 0.194 & 2.473 & $2.667^{* *}$ & 92.72 & 1.84 & 1.91 \\
\hline$F 4$ & & 87.694 & $85.6-89.2$ & 0.575 & 0.203 & 0.127 & 0.331 & 38.54 & 0.41 & 0.66 \\
\hline$F 2$ & \multirow{3}{*}{ FL mm } & 32.861 & $29.2-35.8$ & 0.093 & 0.717 & 0.993 & $1.710^{* *}$ & 58.08 & 3.03 & 3.98 \\
\hline F3 & & 33.5 & $30.2-37.2$ & 1.700 & 0.141 & 2.707 & $2.848^{* *}$ & 95.05 & 4.91 & 5.04 \\
\hline$F 4$ & & 34.193 & $31.2-37.5$ & 1.825 & 0.041 & 3.289 & $3.330^{* *}$ & 98.78 & 5.30 & 5.34 \\
\hline
\end{tabular}

*,** indicated significant and high significant at 0.05 and 0.01 probability level

The estimates of genetic variation make the tasked of breeder easy, the PCV and GCV so as to make effective selection. The data in Table 1 revealed that were comparatively high for seed cotton yield I plant, lint cotton yield, bolls/ plant, seeds/boll and boll weight, which indicate the magnitude of genetic variability persisted in these materials was sufficient for providing rather 
substantial of improvement through application selection of superior progenies. The other characters showed moderate to low values of PCV and GCV such as lint percentage and other fiber characters. It is noteworthy that the advanced generations, $F_{3}$ and $F_{4}$ showed reduction in PCV and GCV values for all studied characters. This was due to reduction in genetic variability and heterozygote as a result of using different selection procedures which exhausted a major part of variability. Similar results were in agreement with those of El-Mansy (2015).

Heritability in broad sense estimates for all characters under study were improved considerably for most studied characters from $F_{2}$ to $F_{3}$ and $F_{4}$ generations. Most characters showed high heritability values over $60.00 \%$. These estimates indicate the possibility to success in the selection of the early generations that were evaluated (EILawendey and El-Dahan, 2012). Heritability values are useful in predicting the expected progress to be achieved through the process of selection, while genetic coefficient of variation along with heritability estimate provide a reliable estimate of the amount of genetic advance to be expected through phenotypic selection (Eranda et al., 2014).

The cotton breeding includes several agronomic and fiber characters, whose association may interfere in the selection process. Thus the knowledge of this correlation allows measuring the magnitude of the relationship among several characters and determines the character on which the selection can be based, to improve yield and other characters. Results from correlation analysis (Table 2) revealed that the genotypic correlation in most cases were higher than phenotypic correlation in both $F_{2}$ and $F_{3}$ generations, indicated that the genetic effects were greater than the environmental effects in the expression of these characters. Lint yield I plant, seed cotton yield I plant, bolls I plant showed highly significant positive desirable phenotypic and genotypic correlation with other yield contributed characters in both $F_{2}$ and $F_{3}$ generations. In the same time boll weight showed desirable significant correlations with other yield characters in both generations. Makhdoom et al., (2010) reported that boll weight is the key independent yield component and play prime role in managing seed cotton yield. Which agreement with Iqbal et al., (2006) and Farooq et al., (2014). The undesirable negative correlation which existed between fiber length with other yield characters in $F_{2}$ and $F 3$ generations were broken and converted to desirable values. Fiber length showed significant positive phenotypic and genotypic correlation with fiber strength through both generations.

Similar results were reported by Ramadan et al. (2014), El-Mansy (2009) and El-Mansy (2015).

Predicted and actual genetic advance from selection procedures for lint yield Iplant alone are presented in Table (3). The highest predicted genetic advance from $F_{2}$ and $F_{3}$ generations were obtained with the index I.w12 followed by I.w2, , I.w23 and I.w3 , I.w123 and I.w13. This was true since lint yield /plant showed significant positive correlation with the other yield contributed characters. The lowest predicted gain for lint yield /plant were observed when selecting for $\left(x_{2}, x_{3}\right.$ and $\left.I_{23}\right)$ lint Iseed followed by selection for seeds/boll and selection index involving seeds/boll with lint/seed, such characters showed insignificant correlation with yield .Similar results in agreement with El-Lawendey et al., ( 2008 ). 
Table (2): The phenotypic and genotypic correlations among studied characters in $F_{2}$ (Blow) and $F_{3}$ ( Above ) generations for study population

\begin{tabular}{|c|c|c|c|c|c|c|c|c|c|c|c|c|c|}
\hline F2/F3 & & BW & SCY/P & LCYIP & Lp\% & B/P & SI & S/B & L/S & Mic & FS & UR\% & fl \\
\hline \multirow[t]{2}{*}{ BW } & ph & & -0.039 & -0.069 & -0.205 & $339 *$ & 0.179 & $671^{\text {** }}$ & -0.064 & 0.111 & 0.034 & -0.043 & 0.171 \\
\hline & $r_{g}$ & & 082 & -0.122 & 253 & $344^{*}$ & 0.108 & 77 & -0.201 & .163 & -0.027 & -0.083 & 0.203 \\
\hline \multirow[t]{2}{*}{ SCYIP } & ph & 0.13 & & $0.980^{* *}$ & 8 & * & 7 & $-0.320^{*}$ & 3 & 49 & 31 & .023 & 0.154 \\
\hline & $r_{g}$ & $0.202^{*}$ & & $0.980^{* *}$ & -0.254 & $961^{\star *}$ & -0.204 & $-0.402^{* *}$ & $-0.345^{*}$ & .001 & -0.115 & -0.053 & 0.141 \\
\hline \multirow[t]{2}{*}{ LCYIP } & $r_{p h}$ & 34 & $91^{* *}$ & & 5 & $*$ & 2 & - & -0.051 & 2 & 31 & 76 & 0.119 \\
\hline & $r_{g}$ & $0.152^{*}$ & $0.993^{* *}$ & & 1 & $9^{\text {** }}$ & $-0.235^{\star}$ & $-0.433^{\star \star}$ & 0.101 & 60 & -0.128 & -0.116 & 0.099 \\
\hline \multirow[t]{2}{*}{ Lp\% } & $r_{p h}$ & 0.009 & 072 & $0.193^{*}$ & & 164 & .043 & 0.085 & $0.800^{* *}$ & 0.143 & -0.010 & $-0.274^{*}$ & -0.214 \\
\hline & $r_{g}$ & $-0.463^{\star *}$ & $0.156^{*}$ & $-0.234^{*}$ & & -0.193 & -0.112 & -0.157 & $0.879^{* *}$ & 0.123 & -0.084 & $-0.313^{*}$ & $-0.249^{*}$ \\
\hline \multirow[t]{2}{*}{$B / P$} & $r_{p h}$ & -0.087 & $0.972^{\star *}$ & $0.963^{\star *}$ & 0.070 & & -0.102 & $-0.490^{* *}$ & -0.190 & 0.015 & -0.038 & 0.006 & 0.100 \\
\hline & $r_{g}$ & 0.029 & $0.982^{\star \star}$ & $0.846^{\star *}$ & $0.224^{*}$ & & -0.229 & $-0.578^{\star \star}$ & $-0.295^{*}$ & -0.013 & -0.095 & -0.014 & 0.085 \\
\hline \multirow[t]{2}{*}{ SI } & $r_{p h}$ & $0.442^{* *}$ & 0.029 & 0.005 & -0.147 & -0.072 & & $0.394^{*}$ & $0.631^{* *}$ & 0.077 & -0.065 & 0.011 & 0.062 \\
\hline & $r_{g}$ & $0.650^{* *}$ & 0.050 & -0.018 & $-0.341^{\star *}$ & -0.061 & & 0.2 & $0.374^{*}$ & 0.056 & -0.313 & -0.095 & -0.039 \\
\hline \multirow[t]{2}{*}{ S/B } & $r_{p h}$ & $946^{* *}$ & 0.130 & 0.129 & 0.013 & -0.084 & $0.422^{* *}$ & & 0.166 & 0.222 & -0.075 & 0.015 & -0.024 \\
\hline & $r_{g}$ & $0.605^{\star *}$ & 0.097 & 0.058 & -0.121 & -0.127 & $0.558^{* *}$ & & -0.018 & 0.211 & -0.136 & -0.026 & \begin{tabular}{|l|}
-0.078 \\
\end{tabular} \\
\hline \multirow[t]{2}{*}{ LIS } & $r_{p h}$ & 299 & 076 & $0.165^{*}$ & $0.768^{\star *}$ & 0.007 & $0.515^{* *}$ & 0.28 & & 0.147 & -0.041 & -0.202 & -0.123 \\
\hline & $r_{g}$ & 070 & 0.169* & $-0.220^{*}$ & 0.57 & $0.148^{*}$ & $0.398^{* *}$ & 0.294 & & 0.132 & -0.220 & $-0.335^{\star}$ & $-0.248^{*}$ \\
\hline \multirow[t]{2}{*}{ Mic } & $r_{p h}$ & $243^{* *}$ & 167 & $0.219^{*}$ & $0.402^{\star *}$ & 0.119 & $0.204^{*}$ & 0.223 & $0.469^{* *}$ & & 0.119 & -0.218 & 0.097 \\
\hline & $r_{g}$ & $0.307^{\star \star}$ & $0.291^{* *}$ & $-0.367^{* *}$ & $0.379^{* \star}$ & $0.242^{*}$ & $0.278^{* *}$ & 0.522 & $0.501^{* *}$ & & 0.133 & $-0.259^{\star}$ & 0.075 \\
\hline \multirow[t]{2}{*}{ FS } & $r_{p h}$ & 0.046 & 0.002 & -0.050 & $-0.396^{* *}$ & -0.015 & 0.057 & 0.035 & $-0.302^{\star *}$ & $-0.335^{\star \star}$ & & 0.103 & $0.262^{*}$ \\
\hline & $r_{g}$ & 0.062 & -0.028 & 0.124 & $-0.687^{\star *}$ & -0.049 & $0.171^{*}$ & -0.210 & $-0.454^{\star *}$ & $-0.343^{\star \star}$ & & 0.104 & $0.451^{* \star}$ \\
\hline \multirow[t]{2}{*}{ UR\% } & $r_{p h}$ & 0.198 & $0.210^{*}$ & 0.153 & $-0.405^{\star \star}$ & $0.172^{*}$ & $0.190^{*}$ & 0.200 & $-0.233^{*}$ & -0.079 & $0.533^{\star *}$ & & 0.160 \\
\hline & $r_{g}$ & $0.507^{* *}$ & $0.412^{\star *}$ & $-0.339 * *$ & $-0.945^{\star *}$ & $0.328^{* *}$ & $0.486^{* *}$ & 0.128 & $-0.460^{* *}$ & $0.191^{*}$ & $0.300^{\star \star}$ & & 0.154 \\
\hline \multirow[t]{2}{*}{ FLmm } & $r_{p h}$ & 0.031 & 052 & 7 & -0.292 & 0.052 & 1 & 24 & $38^{*}$ & 31 & $0.476^{\star *}$ & 0.583 & \\
\hline & $r_{g}$ & $253^{\star \star *}$ & 012 & .003 & .004 & .017 & .042 & -0.217 & 0.045 & $0.267^{*}$ & $0.472^{\star *}$ & $0.897^{\star *}$ & \\
\hline
\end{tabular}

$*,+*$ indicated significant and high significant at 0.05 and 0.01 probability level

Table (3): Predicted and actual genetic advances of lint yield ( $\left.X_{w}\right)$ /plant and selection advances ( $S . A$. \%) from $F_{2}, F_{3}$ and $F_{4}$ generations for different selection procedures in population ( $\mathrm{G.88}$ * Australly 13 )

\begin{tabular}{|c|c|c|c|c|c|c|c|c|c|c|}
\hline & $\Delta g \times W$ & \multicolumn{3}{|c|}{$F 2$} & \multicolumn{4}{c|}{ F3 } & \multicolumn{3}{c|}{ f4 } \\
\hline \multirow{2}{*}{ NO } & Indices & pre. & S.A.\% & Act & act. \% & pre. & S.A.\% & Act & Pre & S.A.\% \\
\hline 1 & $I . W 123$ & 24.133 & 108.46 & 25.782 & 115.88 & 23.40 & 67.78 & 13.638 & 19.68 & 57.02 \\
\hline 2 & $I . W 12$ & 25.349 & 113.93 & 25.026 & 112.48 & 23.35 & 67.63 & 14.593 & 19.68 & 57.02 \\
\hline 3 & $I . W 13$ & 22.182 & 99.69 & 24.026 & 107.99 & 23.30 & 67.49 & 12.755 & 19.67 & 56.97 \\
\hline 4 & $I . W 23$ & 24.614 & 110.63 & 23.119 & 103.91 & 23.03 & 66.71 & 12.045 & 19.66 & 56.96 \\
\hline 5 & $I .123$ & 15.948 & 71.68 & 20.876 & 93.83 & 23.36 & 67.67 & 9.655 & 19.18 & 55.55 \\
\hline 6 & $I . W 1$ & 17.545 & 78.86 & 19.626 & 88.21 & 24.47 & 70.88 & 13.190 & 19.74 & 57.18 \\
\hline 7 & $I . W 2$ & 24.822 & 111.56 & 18.724 & 84.15 & 23.24 & 67.32 & 5.380 & 19.66 & 56.95 \\
\hline 8 & $I . W 3$ & 24.495 & 110.09 & 22.912 & 102.98 & 22.73 & 65.86 & 5.638 & 19.62 & 56.85 \\
\hline 9 & $I .12$ & 15.791 & 70.97 & 21.679 & 97.44 & 23.48 & 68.02 & -2.380 & 18.96 & 54.92 \\
\hline 10 & $I .13$ & 15.698 & 70.55 & 20.27 & 91.10 & 23.27 & 67.42 & 10.347 & 18.87 & 54.67 \\
\hline 11 & $I .23$ & -0.809 & -3.64 & 19.714 & 88.61 & 10.62 & 30.76 & 6.220 & 11.40 & 33.03 \\
\hline 12 & $X W$ & 15.361 & 69.04 & 11.3 & 50.79 & 14.40 & 41.72 & 5.280 & 11.46 & 33.20 \\
\hline 13 & $x 1$ & 6.462 & 29.04 & 8.351 & 37.53 & 14.77 & 42.8 & 5.400 & 11.02 & 31.93 \\
\hline 14 & $x 2$ & -0.318 & -1.43 & 7.916 & 35.58 & -6.75 & -19.55 & 3.120 & -6.68 & -19.36 \\
\hline 15 & $x 3$ & 1.283 & 5.76 & 6.4218 & 28.86 & -2.82 & -8.17 & -2.700 & 2.44 & 7.06 \\
\hline & $m . X W$ F2 & 22.249 & & & & & & $m . x W$ F3 & 34.52 & \\
\hline
\end{tabular}


The highest actual genetic gains from $F_{3}$ generation for lint yield /plant occurred by $I_{\mathrm{w} 123}, I_{\mathrm{w} 12}$ and most selection indices. The actual gains were approximately with predicted advance from $F_{2}$. While, actual advance from direct selection were smaller as compared with obtained from index selection. Actual genetic advance from $F_{4}$ generation were decreased as compared with predicted advance from $F_{3}$.

Deviation of the actual advance from the predicted ones (Figures 1 and 2) were positive and low for most indices, which due to the minor relatively role of non additive effects and the additive genetic effective would appear to be predominant. On the other side high discrepancy was observed between predicted and actual gains from selection when applied selection for seeds/boll, lint Iseed and selection index for seeds/boll with lint/seed this was due to nonadditive gene effect and large affected by environmental factors. Results are in harmony with those reported by Gooda (2001), El-lawendey et al., (2011) and Ramadan et al., ( 2014 ).

Maximum predicted genetic advance for lint yield /plant from $F_{3}$ and $F_{4}$ generations were achieved when selecting for lint yield/ plant, bolls/plant and seeds/boll followed by selecting for three previous characters as well as for lint yield alone. These main attributes for lint yield. On the other side, selecting for seeds $I$ boll and lint Iseed exhibited minimum predicted and actual genetic gains for lint yield /plant followed index involve both characters. The indices $I_{\mathrm{w} 12}$ and Iw123 recorded maximum actual value in $F_{4}$ generation.

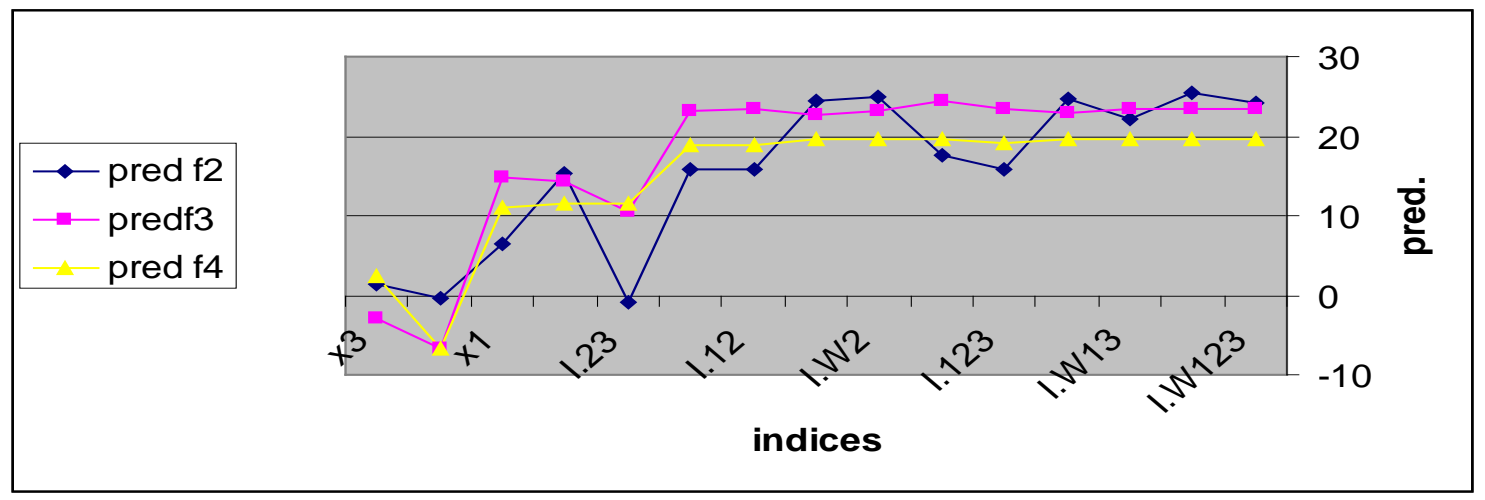

Figure 1. Predicted advance in lint yield/plant improvement curves as a result of using $\mathbf{1 5}$ selection indices in $F_{2}, F_{3}$ and $F_{4}$ generations

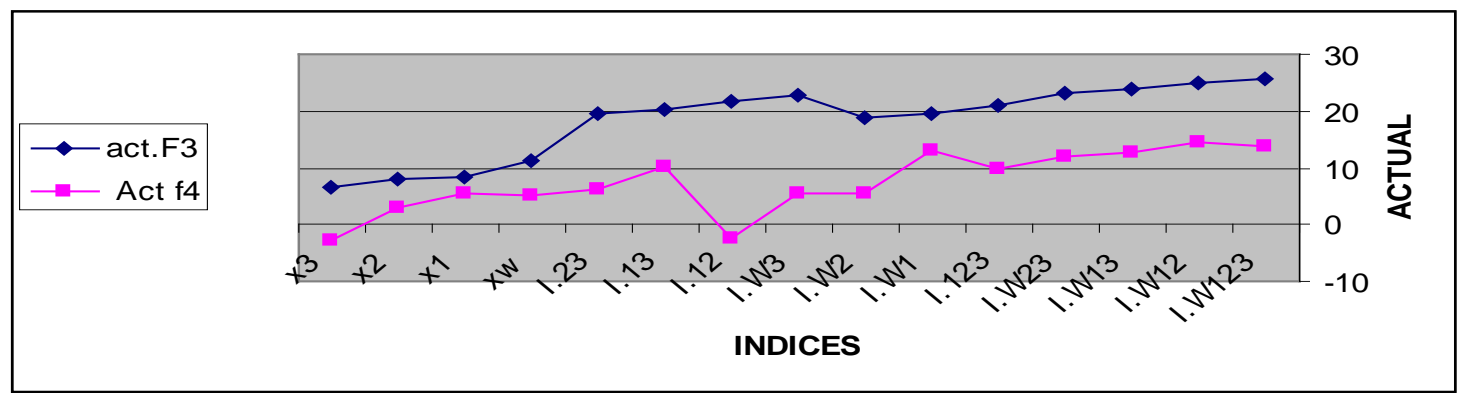

Figure 2. Actual lint yield/plant improvement curve as a result of using 15 selection indices in $F_{3}$ and $F_{4}$ generations. 
High discrepancy was observed between predicted and actual gains from selection for most procedure in $F_{3}$ and $F_{4}$ generation this due to non-additive gene effect and large affected by environment conditions. Also, predicted and actual genetic gains from $F_{4}$ generation were decreased as compared with the previous generations $F_{2}$ and $F_{3}$. This was due to applied of different selection procedures through two cycles which exhausted of most genetic variability. This results were in a good agreement with Ramadan et al. (2014) and El- Mansy (2015).

The mean population was change from $F_{2}$ generation to $F_{4}$ generation by

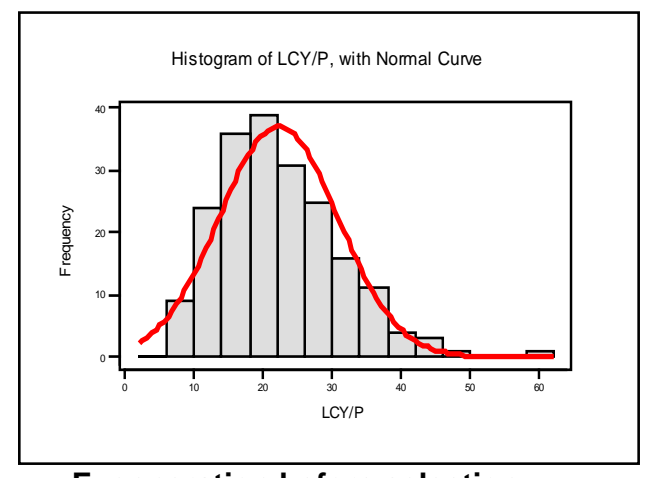

$F_{2}$ generation before selection

(Basic population G.88 x Astrualy 13) effect selection procedures. The mean F4 was higher than F2 generation in lint yield characters as showed in Figure 3.

Estimation predicted advance for all studies characters from indirect selection were depend on genetic variance, covariance and phenotypic variances in $F_{2}$ and $F_{4}$ generations are presented in Table 4 . The results indicated that predicted genetic advance in $F_{2}$ often higher than obtained from $F_{4}$ for most characters. These results indicated that high genetic variability in $F_{2}$ generation were play role in high improvement than $F_{4}$ generation. Similar results with Younis, (1999), Ramdan, et al., (2014) and Abd EL-Aty et al. (2017).

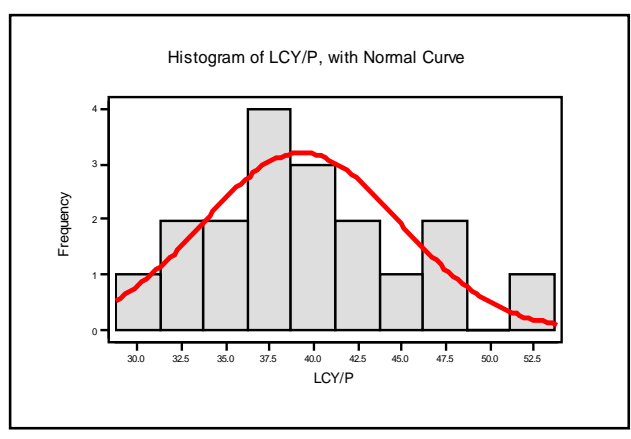

$F_{4}$ generation after selection

Figure 3. The role of selection indices in improvement lint yield trait in $F_{4}$ generation (within population).

Table (4): Predicted genetic advances of most studied characters (from $F_{2}$ (below) and $F_{4}$ (above) generations from indirect selection in population ( G.88*$^{*}$ Australly 13 ).

\begin{tabular}{|c|c|c|c|c|c|c|c|c|c|c|c|c|}
\hline \multirow{4}{*}{ 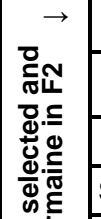 } & & \multicolumn{11}{|c|}{ Predicted genetic advance in selected and unselected characters were detrmained in F4 } \\
\hline & & $\downarrow$ BW & SCYIP & Lp & B/P & SI & S/B & L/S & Mic & FS & UR & fl \\
\hline & BW & 0.2134 & -0.0888 & -0.0583 & -0.127 & -0.037 & 0.13 & -0.061 & 0.076 & 0.125 & 0.035 & -0.0101 \\
\hline & SCY/P & 0.030 & 28.8159 & 0.2101 & 28.23 & -1.245 & -14.16 & -0.483 & -5.345 & -11.52 & 7.468 & 3.7845 \\
\hline . & Lp & -0.1162 & 3.2196 & 2.8472 & 0.16 & 0.86 & -1.27 & 2.563 & -1.033 & -0.533 & -0.524 & -0.993 \\
\hline$\overline{0}$ & B/P & 0.0309 & 16.8395 & 0.4269 & 9.997 & -0.176 & -5.643 & 0.312 & -2.291 & -4.704 & 1.979 & 1.2393 \\
\hline & SI & 0.0691 & 1.082 & -0.4689 & -0.166 & 0.729 & -0.088 & 0.513 & -0.016 & 0.086 & 0.012 & -0.0509 \\
\hline 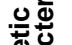 & S/B & 0.0682 & -0.2561 & -0.2392 & -0.611 & 0.105 & 2.893 & -1.16 & 1.98 & 1.523 & -0.307 & 0.0374 \\
\hline$\frac{c}{d}$ & L/S & -0.0545 & 3.5222 & -0.2652 & 1.604 & -0.019 & 0.002 & 0.011 & -0.003 & $-9 E-04$ & -0.001 & -0.0033 \\
\hline 0 & Mic & 0.0197 & 5.8482 & 0.0358 & 1.93 & 0.085 & 0.495 & 6E-04 & 0.666 & 0.338 & -0.158 & -0.0079 \\
\hline & FS & 0.0039 & -0.9494 & -0.6059 & -0.436 & 0.086 & -0.378 & -0.001 & -0.017 & 0.817 & -0.014 & -0.3328 \\
\hline & UR & 0.0506 & 5.5305 & -0.7213 & 1.544 & 0.159 & -0.163 & $-9 E-04$ & 0.085 & -0.12 & 0.639 & -0.0433 \\
\hline 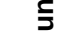 & $\mathrm{FL}$ & 0.0579 & -0.821 & 0.5358 & -0.644 & 0.018 & -0.389 & 0.002 & 0.118 & 0.02 & 0.276 & 3.7246 \\
\hline
\end{tabular}


Improvement in unselected characters as a result application 15 selection procedure in $F_{3}$ are presented in Table 5. Actual gains in unselected characters were positive value for boll weight, seed cotton yield I plant, lint percentage, seed index, micronaire value and fiber length for 15 selection procedure. The improvement depend on positive genetic association between select and other unselected characters. The index selection were superior in actual advance in most characters as compared with direct selection for lint yield, bolls/plant, seeds/boll and lint/ seed except lint percentage, seed index and fiber strength. The direct selection for seed /boll and lint /seed recorded improvement in lint percentage, seed index and micronair reading (negative value was disable) than other indices.

The actual advance in $F_{4}$ generation are presented in Table 6 . The indices;
Iw123, I.w12, I.W13, I.w23, I.W1 and I.13 recorded high actual advance in seed cotton yield I plant . The actual genetic advance improvement in $F_{4}$ generation decreased significantly from the $F_{3}$ generation. As a result of the depletion of genetic variances, the continuation of improvement, the stopping of the feasibility of selection, and the stability of genotypes within the population. These results coincide with Ramdan et al 2014, El-Mansy, (2015) and Abd El-Aty et al 2017.

The role of selection in improvement is that acts on the genetic variances within a population, isolates and increases the desired genetic frequency within the population, and thus, the population means changes towards to a desired value. Accordingly, the top 12 families with the most characteristics were isolated from $F_{4}$ are presented in Table 7.

Table 5. Improvement in unselected characters actual and actual advance as a result application of 15 selection procedures in $\mathrm{F}_{3}$ generation .

\begin{tabular}{|c|c|c|c|c|c|c|c|c|c|c|c|c|c|c|c|}
\hline & & \multicolumn{7}{|c|}{ Actual from F3 } & \multicolumn{7}{|c|}{ Actual \% } \\
\hline & Ind & BW & SCYIP & Lp & SI & Mic & FS & FL & BW & SCYIP & Lp & SI & Mic & FS & $\mathbf{F L}$ \\
\hline 1 & I.W123 & 0.47 & 65.04 & 1.33 & 1.16 & 0.13 & 1.16 & 1.09 & 17.24 & 108.69 & 3.59 & 11.75 & 3.16 & 12.17 & 3.31 \\
\hline 2 & I.W12 & 0.47 & 62.32 & 1.59 & 1.06 & 0.04 & 1.34 & 1.61 & 17.05 & 104.14 & 4.29 & 10.75 & 1.04 & 14.12 & 4.91 \\
\hline 3 & I.W13 & 0.43 & 60.56 & 1.3 & 1.10 & 0.09 & 1.33 & 1.71 & 15.86 & 101.21 & 3.49 & 11.10 & 2.33 & 13.97 & 5.20 \\
\hline 4 & I.W23 & 0.42 & 58.3 & 1.26 & 1.18 & 0.14 & 1.32 & 1.74 & 15.41 & 97.43 & 3.39 & 11.92 & 3.61 & 13.82 & 5.28 \\
\hline 5 & I.123 & 0.40 & 53.46 & 0.88 & 1.20 & 0.12 & 1.44 & 1.59 & 14.67 & 89.33 & 2.38 & 12.12 & 3.04 & 15.17 & 4.85 \\
\hline 6 & I.W1 & 0.37 & 48.69 & 1.48 & 1.21 & 0.19 & 1.30 & 0.50 & 13.66 & 81.37 & 3.98 & 12.23 & 4.81 & 13.68 & 1.52 \\
\hline 7 & I.W2 & 0.38 & 46.55 & 1.42 & 1.22 & 0.22 & 1.37 & 0.63 & 13.85 & 77.79 & 3.83 & 12.32 & 5.41 & 14.35 & 1.92 \\
\hline 8 & I.W3 & 0.40 & 58.77 & 0.90 & 1.19 & 0.09 & 1.35 & 1.45 & 14.75 & 98.21 & 2.43 & 12.07 & 2.18 & 14.16 & 4.41 \\
\hline 9 & I.12 & 0.35 & 56.35 & 0.59 & 1.11 & 0.05 & 1.36 & 1.38 & 13.00 & 94.17 & 1.59 & 11.18 & 1.13 & 14.31 & 4.20 \\
\hline 10 & I.13 & 0.38 & 50.8 & 1.34 & 1.21 & 0.18 & 1.32 & 0.71 & 14.03 & 84.90 & 3.62 & 12.26 & 4.52 & 13.90 & 2.15 \\
\hline 11 & 1.23 & 0.36 & 49.93 & 1.12 & 1.16 & 0.15 & 1.33 & 0.72 & 13.01 & 83.43 & 3.01 & 11.70 & 3.69 & 14.01 & 2.20 \\
\hline 12 & $\mathbf{x w}$ & 0.78 & 21.63 & 0.82 & 1.33 & 0.33 & 1.25 & 0.75 & 28.59 & 36.15 & 2.21 & 13.43 & 8.29 & 13.12 & 2.28 \\
\hline 13 & $x 1$ & 0.73 & 20.92 & 0.80 & 1.45 & 0.27 & 1.25 & 0.45 & 26.92 & 34.97 & 2.15 & 14.70 & 6.65 & 13.19 & 1.36 \\
\hline 14 & $x 2$ & 0.34 & 15.42 & 3.00 & 1.75 & -0.17 & 1.35 & 0.69 & 12.47 & 25.76 & 8.09 & 17.68 & -4.21 & 14.17 & 2.10 \\
\hline 15 & $x 3$ & 0.32 & 11.61 & 3.04 & 1.71 & -0.10 & 1.30 & 0.66 & 11.89 & 19.41 & 8.18 & 17.29 & -2.46 & 13.71 & 2.00 \\
\hline \multicolumn{2}{|c|}{ M. F2 Gen. } & 2.73 & 59.84 & 37.13 & 9.88 & 4.0 & 9.52 & 32.86 & 2.73 & 59.84 & 37.13 & 9.88 & 4 & 9.52 & 32.86 \\
\hline
\end{tabular}


Genetic gain and selection criteria effects on lint yield and yield components ......

Table 6. Improvement in unselected characters actual and actual advance as a result application 15 selection procedure in $\mathrm{F}_{4}$ generation.

\begin{tabular}{|c|c|c|c|c|c|c|c|c|c|c|c|c|c|c|c|}
\hline \multirow[b]{2}{*}{ No. } & & \multicolumn{7}{|c|}{ Actual from F4 } & \multicolumn{7}{|c|}{ Actual \% from F4 } \\
\hline & & $B W$ & SC & $L P$ & $s$ & MIC & FS & FI & $N$ & sc & $P$ & SI & MIC & FS & $F L$ \\
\hline 1 & I.w123 & -0.028 & .740 & 438 & 0.047 & .055 & 145 & 0.508 & -0.89 & 37.57 & 14 & 0.42 & -1.33 & 1.33 & 1.52 \\
\hline 2 & I.w1 & .045 & .440 & 355 & .167 & .130 & 007 & 1.338 & -1.42 & 0.57 & .92 & 1.49 & 3.15 & 0.07 & 3.99 \\
\hline 3 & I.W13 & -0.001 & 2.296 & 0.174 & -0.039 & -0.061 & 126 & 1.106 & -0.04 & 35.96 & 0.45 & -0.35 & -1.48 & 1.16 & 3.3 \\
\hline 4 & I.w2 & 0.005 & 29.680 & 0.455 & 0.155 & -0.065 & 305 & 0.880 & 0.16 & 33.05 & 18 & 1.38 & 1.57 & .8 & .63 \\
\hline 5 & 1.123 & 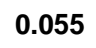 & 30 & 180 & 17 & 80 & 45 & 438 & .74 & .27 & 5 & .83 & .94 & 01 & .29 \\
\hline 6 & I.W1 & -0.032 & 29.215 & 555 & 317 & .130 & 395 & -0.138 & -1.03 & 32.53 & 4.04 & 2.83 & -3.15 & 3.63 & -0.41 \\
\hline 7 & I.W2 & 0.018 & 17.359 & -1.251 & -0.070 & -0.186 & 0.307 & 0.975 & 0.55 & 19.33 & -3.25 & -0.62 & -4.51 & 2.83 & 2.91 \\
\hline 8 & I.V & 0 & 1 & 5 & -1 & 2 & 3 & 1.317 & 0.95 & 8 & 5 & 99 & 37 & 5 & 3 \\
\hline 9 & 1.12 & 0.130 & .235 & .833 & -0.045 & 0.145 & 657 & 2.138 & 4.1 & -2.49 & -4.76 & -0.4 & 3.51 & .04 & .38 \\
\hline 10 & 1.13 & 0.038 & 25.173 & 0.522 & 0.147 & -0.022 & 0.503 & 0.575 & 1.21 & 28.03 & 1.35 & 1.31 & -0.52 & 4.63 & 1.72 \\
\hline 11 & 1.23 & -0.020 & 12.140 & 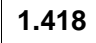 & 0.605 & -0.380 & 0.395 & $0.0<2$ & -0.63 & 13.52 & (.10 & 5.39 & -9.2 & 3.63 & 0.07 \\
\hline 12 & $x w$ & 0.088 & 14.898 & .570 & -0.137 & 0.137 & 520 & -0.217 & 2.79 & 16.59 & -1.48 & -1.22 & 3.31 & 4.78 & -0.65 \\
\hline 13 & $\mathrm{X} 1$ & -0.032 & 10.665 & 1.180 & 0.730 & 0.170 & 0.895 & -0.938 & -1.03 & 11.88 & 0 & 6.51 & 4.12 & 8.23 & -2.8 \\
\hline 14 & $x$ & 0.124 & 71 & .326 & $-c$ & 0.19 & 657 & -0.450 & 0.00 & 9.70 & -0.85 & -1.35 & 4.72 & 6.04 & -1.34 \\
\hline 15 & $x 3$ & 0.163 & -4.768 & -1.087 & -0.095 & 0.220 & 0.795 & 1.042 & 5.15 & -5.31 & -2.82 & -0.85 & 5.33 & 7.31 & 3.11 \\
\hline \multicolumn{2}{|c|}{ M.F3 } & 3.17 & 31 & .52 & 22 & .10 & 0.88 & 3.50 & 3.17 & 89.81 & 38.52 & 11.22 & 4.10 & 10.88 & 33.50 \\
\hline
\end{tabular}

Table 7. Rank of the best families selected in the F4 generation on the recipe for lint yield I plant.

\begin{tabular}{|c|c|c|c|c|c|c|c|c|c|c|c|c|c|c|c|}
\hline 10 & 46 & 6 & 3 & 3.10 & 94.90 & 37.80 & 39.80 & 30.58 & 11.50 & 18.80 & 0.0760 & 3.45 & 10.65 & 88.00 & 33.60 \\
\hline 9 & 106 & 9 & 5 & 3.30 & 106.20 & 38.90 & 36.60 & 32.18 & 11.15 & 22.00 & 0.0644 & 4.15 & 11.58 & 87.90 & 32.60 \\
\hline 8 & 121 & 16 & 9 & 3.20 & 107.60 & 39.10 & 36.40 & 34.28 & 11.48 & 19.00 & 0.0656 & 4.05 & 11.05 & 88.20 & 33.50 \\
\hline 5 & 131 & 19 & 10 & 3.20 & 109.00 & 43.70 & 40.10 & 34.08 & 12.15 & 19.30 & 0.0814 & 4.05 & 11.90 & 88.10 & 33.50 \\
\hline 2 & 139 & 21 & 11 & 3.20 & 123.50 & 46.50 & 37.70 & 38.88 & 11.85 & 20.40 & 0.0717 & 4.05 & 11.13 & 88.00 & 36.40 \\
\hline 12 & 142 & 22 & 12 & 3.10 & 96.30 & 36.90 & 38.30 & 31.35 & 11.33 & 21.00 & 0.0702 & 4.05 & 11.18 & 87.20 & 34.00 \\
\hline 11 & 183 & 30 & 16 & 3.10 & 100.50 & 37.60 & 37.40 & 32.73 & 11.10 & 20.40 & 0.0662 & 4.20 & 11.35 & 86.90 & 36.50 \\
\hline 3 & 194 & 31 & 17 & 3.20 & 118.20 & 46.30 & 39.10 & 37.28 & 11.03 & 21.00 & 0.0709 & 4.23 & 11.30 & 88.00 & 32.40 \\
\hline \multicolumn{4}{|c|}{ Mean selected familes From F4 } & 3.20 & 109.80 & 42.10 & 38.30 & 34.80 & 11.30 & 19.80 & 0.0701 & 4.00 & 11.20 & 87.70 & 34.50 \\
\hline \multicolumn{4}{|c|}{ M.F2 } & 2.73 & 59.84 & 22.25 & 37.13 & 21.99 & 9.88 & 17.03 & 0.0580 & 4.00 & 9.52 & 84.15 & 32.86 \\
\hline \multicolumn{4}{|c|}{ M.F3 } & 3.17 & 89.81 & 34.52 & 38.52 & 28.53 & 11.22 & 19.35 & 0.0700 & 4.10 & 10.88 & 85.39 & 33.50 \\
\hline \multicolumn{4}{|c|}{ M.F4 } & 3.19 & 102.55 & 39.28 & 38.29 & 32.24 & 11.27 & 20.33 & 0.0700 & 4.10 & 11.29 & 87.69 & 34.19 \\
\hline \multicolumn{4}{|c|}{ cheek } & 3.20 & 68.48 & 24.60 & 36.03 & 21.35 & 11.03 & 19.95 & 0.0620 & 4.00 & 9.38 & 84.85 & 33.43 \\
\hline
\end{tabular}


The selected families were exceeded $F_{3}$ families mean for all yield potentials and fiber quality characters. The breeder may use these selected families in breeding programs aimed at improving yield. The selection families were exceeded $F_{3}$ families mean for all yield potentials and fiber quality characters. The breeder may use these selected families in breeding programs aimed at improving yield and quality in cotton.

\section{REFERENCES}

Abd El-Aty, M.S., F.A. Soror, B.M. Ramadan and A.E. El-Shamy (2017). Genetic advance from some applied selection procedures in segregating population of the cotton cross (G.75×Sea Island) $\times$ (G.89×Pima S6) . The 11th Inter. Plant Breed. Conf. KafrEl-Sheikh, Univ., Egypt 17-18 Oct. 1-9.

Arauja, L. F., F. C. Neta and E. Bleicher (2012). Correlations and path analysis in components of fiber yield in cultivars of Upland cotton. Bragantia, Compainas 71 (33): 328-335.

Burton, G. W. (1952). Quantitative inheritance in grasses. Proc. $6^{\text {th }}$ Internat. Grassland Congr. 1 : 277-283.

Desalegn, Z., N. Ratana Dilok and R. Kaveeta (2009). Correlation and heritability for yield and fiber quality parameters of Ethiopian cotton estimated from 15 diallel cross. Kasetstart J. Nat. Sci. 34 (1) : 1-11.

El-Lawendey, M. M., Y. A. Soliman, A. R. Abd El-Bary and Y.M. El-Mansy (2008). Using fourteen selection procedures to evaluate predicted and realized genetic gain in the cotton cross Giza 86 x Suvin. Egypt. J. Plant Breed. 12(1): 157-175.

El-Lawendey, M.M and M.A.A. El-Dahan (2012). Comparison between direct and indirect selection and two indices in segregating populations of cotton
(Gossypium barbadense L.). J. Agric. Res. Kafer El-Sheikh Univ., 38(1): 3753.

El-Lawendey, M.M., Y.M. El-Mansy and M.A.A. El-Dahan (2011). Economic values effects on genetic gains of lint cotton yield and its components using selection indices. Minufiya J. Agric. Res. 36 (6): 1649-1668.

El-Mansy, Y.M. (2015). Relative efficiency of direct and indirect selection with selection indices for improving some economic characters in cotton (G. barbadense L.) J. Agric. Res. Kafr ElSheikh Univ., 41 (1): 192- 215.

El-Mansy, Y.M. (2009). Cluster analysis with selection index for improvement some economic characters in some cotton genotypes. $1^{\text {st }}$ Nile Delta Conference. Fac. of Agric. Minufia University 135-155.

El-Mansy, Y.M. (2009). Cluster analysis with selection index for improvement some economic characters in some cotton genotypes. $1^{\text {st }}$ Nile Delta Conference. Fac. of Agric. Minufia University 135-155.

Erande, C. S., H. V. Kalpande, S. K. Chavan, V. S. Patil and M. R. Puttawar (2014). Genetic variability, correlation and path analysis among different traits in desi cotton. African J. Agric. Res., 9 (29): 2278-2286.

Falconer, D. S. (1989). Introduction to quantitative genetics, Oliver and Boyd Edinburgh, London.

Falconer, D. S. and T. F. C. Muckey (1996). Introduction of quantitive genetic. 4th ed., Longman, England, P. 464.

Farooq, M.A., R.Z. Farooq and F. Hahi (2014). Correlation and path coefficient analysis of earliness fiber quality and yield contributing traits in cotton. J. of Animal and Plant Sci. 24 (3): 781-790. 
Gooda, B.M.R. (2001). Application of certain selection techniques in evaluating and maintaining Egyptian cotton varieties. M.Sc. Thesis, Fac. Agric., Kafr El-Sheikh, Tanta University, Egypt.

Hazel, L.N. (1943). The genetic basis for constructing selection indices. Genetics 28: 476-490.

Iqbal, M., K. Hayat, R. S. Khan, A. Sadiq and N. Islam (2006). Correlation and path coefficient analysis for earliness and yield traits in cotton. Asian $\mathbf{J}$. Plant Sci., 5(2): 341-344.

Jesus, J., C. Jose, J. S. Castellans and A. S. Varda (2006). A selection index method based on eigen analysis. Crop Sci., 46: 1711-1721.

Kearsy, M. and H. S. Pooni (1996). Genetical analysis of quantitative traits. Chapman and Hall, London.

Miller, P.A. and J.O. Rawlings (1967). Selection for increased lint yield and correlated responses in upland cotton, Gossypium hirsutum L. Crop Sci. 7: 637-640.

Makhdoom, K., N. Khan, S. Batool, D. Hussain and M. Sajjad (2010). Genetic aptitude and correlation studies in $\mathbf{G}$. hirsutum L. Pak. J. Bot., 42: 20112017.
Ramdan, B.M., Y.M. El-Mansy, M.A.ALAmeer and M.A. Abou-El-Yazied (2014). Improvement of some economic characters through direct selection in Egyptian cotton Egypt. J. Plant Breed. 18 (4): 783-797.

Robinson, H.F., R.E. Comstock and P.H. Harvey (1951). Genetic and phenotypic correlations in corn and their implications in selection. Agron. J. 43: 283-287.

Smith, H.F. (1936). A discriminate function for plant selection. Ann. Eugenics 7: 240-250.

Soliman, Y.A. and M.M. El-Lawendey (2008). Relative efficiency of selection indices for improving lint yield in two intraspecific cotton crosses. Egypt. J. Agric. Res., 86(1): 207-222 .

SPSS (1995). SPSS computer users guide, USA.

Walker, J.T. (1960). The use of a selection index technique in the analysis of progeny row data. Emp. Cott. Gr. Rev. 37: 81-107.

Younis, F.G. (1999). Predicted and realized responses to selection procedures for improving yield and its components in Egyptian cotton (G. barbadense L.). Al-Azhar J. Agric. Res., 30: 17-23 
العائد الوراثى المتحقق بالانتخاب وتاثيره على محصول الثعر ومكونات المحصول فى عشيرة انعزليه من القطن ( Giza 88 x A13)

\author{
بلير مصطفي رمضان \\ معهد بحوث القطن - مركز البحوث الزراعية - جيزة - مصر مدري
}

المكاسب الوراثية من تطبيق دليل الانتخاب Index Selection مهمة جدا في برامج التربية ولذلك كان الهدف من تلك الكي

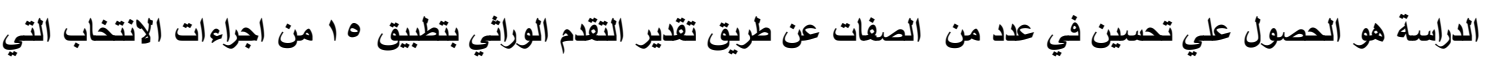
تضم 11 دليل انتخابي تتبع دليل الانتخاب Index Selection و ؛ ادلة انتخاب مباشر و تقيم التيم التحسين الوراثي لكل دليل

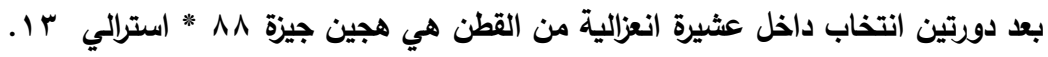

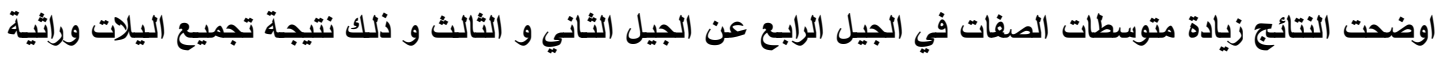

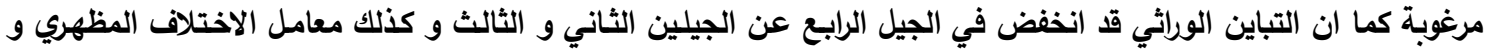

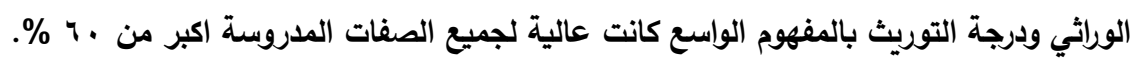

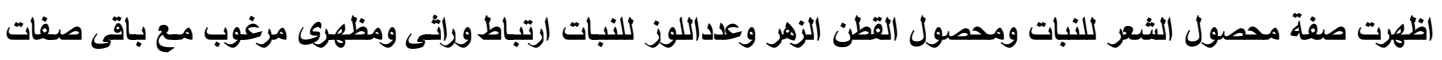
مكونات المحصول لكل من الجيل التانى والثالث كما وجد ارتباط معنوى مرغوب بين صفى وزن اللوزة مع صفات المحصول الاخرى.

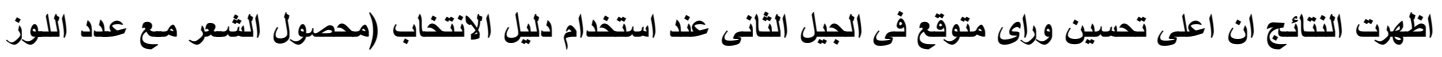

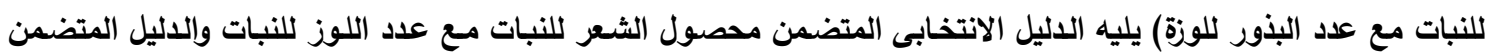
محصول الثعر للنبات مع عدد البذور للوزه وكمية الثعر على البذره.فيما كان اعلى تحسين فعلى فى الجيل الثالث تم الحصول

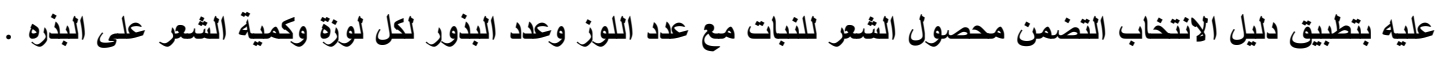

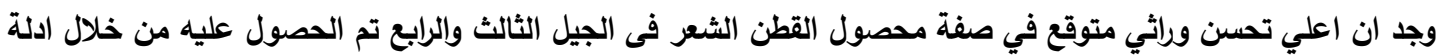

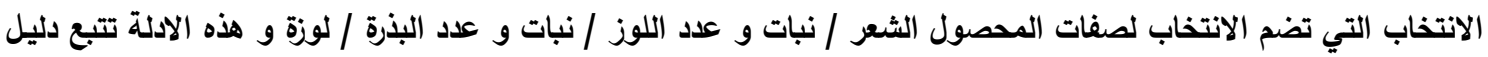

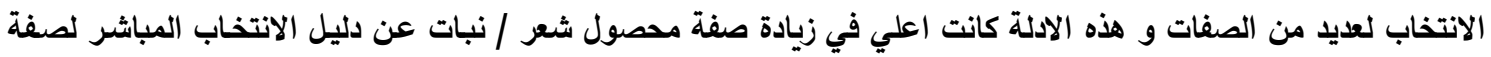

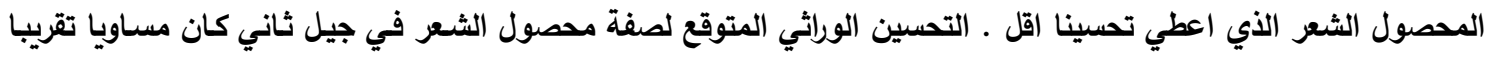

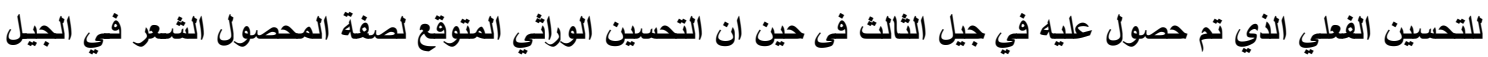

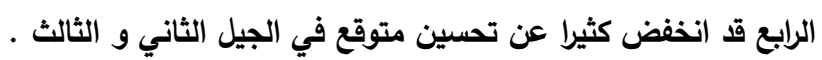
اظهرت النتائج ان الانحراف بين قيم التحسين الوراثى الفعلى ةالمتوقع ذات قيمئ صغيل صغيرة موجبه لمعظم ادلة الانتخاب ممـا

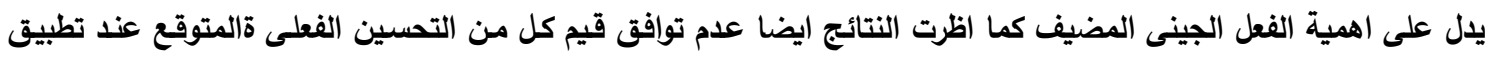
الانتخاب المباشر لصفة عدد البذور فى اللوز والانتحاب لصفة كمية الثعر لكل بذرة والدليل الانتخابى المتضمن كلا الصفتين.

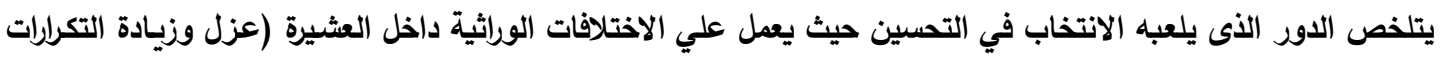

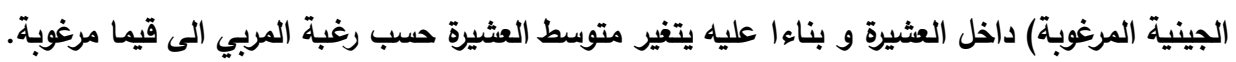

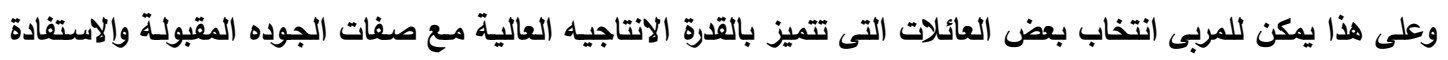

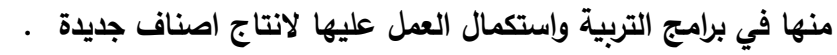
أسماء السادة المحكمين معهز بحوث القطن - مركز البحوث الزراعية

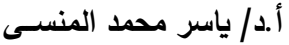
أ.د/ حسان عبدالجيد دوام كلية الزراعة - جامعة المنوفية 